ISSN 2080-1653

\author{
JAN FAZLAGIĆ \\ Uniwersytet Ekonomiczny w Poznaniu, Polska \\ Poznań University of Economics and Business, Poland

\section{ROBERT SKIKIEWICZ} \\ Uniwersytet Ekonomiczny w Poznaniu, Polska \\ Poznań University of Economics and Business, Poland
}

\title{
Analiza kształtowania się barier prowadzenia działalności w wybranych działach sektora usług w świetle zmian klimatu koniunkłury w województwach Polski
}

\section{Analysis of Barriers to Economic Activity Shaping in Selected Branches of the Services Sector in the Light of the Business Climate Changes in Polish Regions}

Streszczenie: Uzyskiwane przez przedsiębiorstwa wyniki ekonomiczne są uzależnione nie tylko od jakości posiadanych zasobów materialnych i niematerialnych, ale także od oddziaływania czynników zewnętrznych, które mogą stymulować rozwój przedsiębiorstwa lub ograniczać go. Czynniki z otoczenia przedsiębiorstwa, które w istotnym stopniu mogą wpływać na warunki prowadzenia działalności gospodarczej, klasyfikuje się jako bariery dla prowadzenia działalności. W opracowaniu podjęto próbę analizy barier dla prowadzenia działalności na tle koniunktury gospodarczej w wybranych sekcjach sektora usług oraz wyciągnięcia odpowiednich wniosków. Kolejność województw w rankingu według średniego poziomu barier w poszczególnych sekcjach sektora usług (H, I oraz J) dość znacznie się różni. Niewiele jest województw o wysokim poziomie barier równocześnie we wszystkich trzech sekcjach. Zależności między natężeniem barier dla prowadzenia działalności oraz ogólnym klimatem koniunktury na poziomie województw są słabsze niż na poziomie całego kraju, przy czym w znacznej większości przypadków pozostają ujemne. W opracowaniu zastosowano miary statystyki opisowej, analizę korelacji oraz metodę Warda. Pozycja danego województwa na tle pozostałych województw pod względem poziomu koniunktury ulega zmianie w czasie. Wraz z poprawą koniunktury gospodarczej w wyodrębnionych segmentach województw zasadniczo zmniejsza się natężenie barier dla prowadzenia działalności gospodarczej.

\begin{abstract}
The economic performance of business enterprises depends not only on the quality of its tangible and intangible resources but also on the influence of external factors which may either stimulate a company's growth or hinder it. Those external factors which may substantially influence the general conditions of economic performance are classified as barriers to doing business. The aim of this paper is to investigate the relationship between the business barriers and the general business climate. The intensity of barriers in different Polish regions is analysed against the general business climate indices for the Polish economy in selected branches of the service sector in the Polish economy. The ranking of Polish regions in terms of the average intensity of barriers in the service sector (sections $\mathrm{H}$, I and J) is substantially diversified. Only a few regions are characterised by high intensity of business barriers in all three sections. The relationships between the intensity of barriers and the general business climate at the regional level are weaker than at the country level
\end{abstract}


and remain predominantly negative. The position of a region in the general population of regions in terms of business climate varies in time. The following statistical methods have been applied: descriptive statistics measures, correlation analysis, Ward method. The improvement of general business climate in the selected branches of economy in regions, in principle, decreases the intensity of barriers to doing business.

Słowa kluczowe: koniunktura; przedsiębiorczość; rozwój regionalny; sektor usług

Keywords: business climate; entrepreneurship; regional development; services sector

Otrzymano: 31 grudnia 2016

Received: 31 December 2016

Zaakceptowano: 18 maja 2018

Accepted: 18 May 2018

Sugerowana cytacja / Suggested citation:

Fazlagić, J., Skikiewicz, R. (2018). Analiza kształtowania się barier prowadzenia działalności w wybranych działach sektora usług w świetle zmian klimatu koniunktury w województwach Polski. Prace Komisji Geografii Przemysłu Polskiego Towarzystwa Geograficznego, 32(2), 216-228. https://doi.org/10.24917/ 20801653.322.15

\section{WSTĘP}

Funkcjonowanie podmiotów gospodarczych jest uzależnione od warunków prowadzenia działalności gospodarczej. Osiągane przez nie efekty w postaci wyników sprzedaży oraz wyników finansowych są konsekwencją nie tylko posiadanych zasobów wewnętrznych oraz umiejętności firmy, ale także oddziaływania czynników zewnętrznych, które mogą stymulować rozwój przedsiębiorstwa lub ograniczać go (Pierścionek, 2003). Czynniki z otoczenia przedsiębiorstwa, które w istotnym stopniu mogą niekorzystnie oddziaływać na warunki prowadzenia działalności gospodarczej, klasyfikuje się jako bariery dla prowadzenia działalności. Analizy występowania tego rodzaju barier prowadzone są zwykle $\mathrm{w}$ ujęciu rocznym i prezentowane $\mathrm{w}$ raportach na poziomie krajowym i międzynarodowym - m.in. ranking Banku Światowego pod nazwą Doing Business w Polsce 2015 (2016), raport Związku Przedsiębiorców i Pracodawców o warunkach prowadzenia firm w Polsce (Warunki prowadzenia firm w Polsce, 2016). Ponadto w krajach Unii Europejskiej poziom barier dla prowadzenia działalności gospodarczej jest regularnie monitorowany $w$ ramach badań prowadzonych metodą testu koniunktury. Wiedza o kształtowaniu się barier dla prowadzenia działalności daje możliwość podjęcia działań, które umożliwią złagodzenie ich skutków dla przedsiębiorstw.

Wśród barier dla prowadzenia działalności gospodarczej wyróżnia się najczęściej następujące: finansowe, rynkowe, prawne, społeczne oraz informacyjne (Zdrajkowska, Zakrzewska-Bielawska, 2006). W innej klasyfikacji zwraca się uwagę na następujący podział barier dla prowadzenia działalności gospodarczej: prawne, administracyjne, ekonomiczne, edukacyjne, zarządzania (Leoński, 2014). Z kolei w badaniach barier dla przedsiębiorczości prowadzonych w ujęciu rocznym przez Ministerstwo Gospodarki wyróżnia się następujące ich kategorie: wysokość podatków i opłat przewidzianych prawem, skomplikowanie przepisów prawnych, brak odpowiednich kwalifikacji siły roboczej, konkurencja innych małych i średnich przedsiębiorstw, konkurencja dużych przedsiębiorstw, warunki lokalowe (wysokość czynszu, zakup lokalu) oraz inne (Przedsiębiorczość w Polsce, 2014). 
Z analiz wynika, że w przypadku niemal połowy barier dla prowadzenia działalności w dziale 64 sekcji K (finansowa działalność usługowa, z wyłączeniem ubezpieczeń i funduszów emerytalnych) występuje statystycznie istotna ujemna zależność z tempem wzrostu PKB Polski. Poprawa sytuacji gospodarczej prowadziła do spadku poziomu barier dla prowadzenia działalności (Skikiewicz, 2014). Ponadto przeprowadzone dla sektora budowlanego analizy wykazały, że między wskaźnikiem określającym ogólne natężenie barier prowadzenia działalności oraz ocenami sytuacji finansowej w prawie wszystkich województwach Polski występują silne lub umiarkowane ujemne zależności (Mikołajczak, Skikiewicz, 2014). Analiza kształtowania się szeregów danych przekrojowych dla krajów Unii Europejskiej ukazuje, iż w grupach krajów charakteryzujących się lepszą koniunkturą w sektorze usług natężenie barier dla prowadzenia działalności również jest niższe, a wskaźnik braku barier kształtuje się na wyższym poziomie w porównaniu do pozostałych krajów (Skikiewicz, 2016).

W artykule została podjęta próba oceny zależności występujących między poziomem barier ograniczających prowadzenie działalności podmiotów gospodarczych w sektorze usług (w sekcjach $\mathrm{H}$ - transport i gospodarka magazynowa, I - zakwaterowanie i usługi gastronomiczne, J - informacja i komunikacja) a ogólnym klimatem koniunktury gospodarczej.

Głównym celem artykułu jest ocena wpływu ogólnego klimatu koniunktury na występowanie barier ograniczających prowadzenie działalności gospodarczej w sekcjach H, I oraz J. Analizy zostały przeprowadzone zarówno na podstawie danych ogólnokrajowych, jak i danych dla poszczególnych województw. Takie ujęcie pozwala na wskazanie prawidłowości występujących na poziomie ogólnokrajowym, jak również na dokonanie porównań między poszczególnymi województwami.

W ramach prowadzonych analiz zostały wykorzystane metody statystyki opisowej, przeprowadzono analizę współzależności między zmiennymi, a ponadto dokonano segmentacji województw na podstawie wskaźników koniunktury gospodarczej z zastosowaniem metody Warda. W przypadku metody Warda grupowanie obiektów przeprowadzane jest na podstawie macierzy odległości tworzonej w oparciu o zestaw zmiennych segmentacyjnych. Metoda ta opiera się na algorytmie, w ramach którego skupienia podlegające łączeniu dobierane są tak, aby uzyskać możliwie najmniejszy przyrost wariancji. Na największą skuteczność metody Warda w tworzeniu homogenicznych skupień oraz jej przewagę nad innymi hierarchicznymi metodami analizy skupień wskazują wyniki wielu analiz (Hands, Everitt, 1987; Ferreira, Hitchcock, 2009).

Analizy prowadzone są w oparciu o dane pochodzące $\mathrm{z}$ badań realizowanych metodą testu koniunktury przez Główny Urząd Statystyczny w sektorze usług w ujęciu miesięcznym. W ramach badania realizowanego przez Główny Urząd Statystyczny przedstawiciele przedsiębiorstw z sektora usług określają występowanie 11 różnych barier prowadzenia działalności gospodarczej: niedostateczny popyt, niedobór wykwalifikowanych pracowników, niedobór powierzchni usługowej i/lub wyposażenia, koszty zatrudnienia, trudności z uzyskaniem kredytu, wysokie obciążenia na rzecz budżetu, konkurencja firm krajowych, konkurencja firm zagranicznych, niejasne i niespójne przepisy prawne, niepewność ogólnej sytuacji gospodarczej, inne (Badanie koniunktury gospodarczej, 2016). Na podstawie powyższych wskaźników barier został wyznaczony syntetyczny wskaźnik barier, jako średnia arytmetyczna nieważona. Zakres czasowy badania obejmuje okres od stycznia 2011 do października 2016 roku. 


\section{CHARAKTERYSTYKA POZIOMU BARIER DLA PROWADZENIA DZIAŁALNOŚCI W WOJEWÓDZTWACH W SEKCJI H, I ORAZ J}

Poziom barier prowadzenia działalności gospodarczej w sekcjach $\mathrm{H}$, I oraz J wykazuje zróżnicowanie pomiędzy poszczególnymi województwami. W analizowanym okresie od stycznia 2011 do października 2016 roku - w poszczególnych województwach maksymalna wartość syntetycznego wskaźnika barier często była niemal dwukrotnie wyższa od jego wartości minimalnej, co wskazuje również na istotne jego zmiany w czasie.

Syntetyczny wskaźnik barier dla sekcji $\mathrm{H}$ - transport i gospodarka magazynowa kształtował się w całym analizowanym okresie na poziomie najwyższym w województwach: małopolskim $(37,1)$, lubuskim $(35,6)$ oraz łódzkim $(34,8)$ (tab. 1). Oznacza to, że podmioty gospodarcze z sekcji H spotykały się z największym natężeniem barier ograniczających prowadzenie działalności w powyższych trzech województwach. Z kolei najniższe wartości syntetycznego wskaźnika barier i najkorzystniejsze warunki prowadzenia działalności występowały w województwach - podlaskim $(27,0)$, dolnośląskim $(26,7)$ oraz warmińsko-mazurskim $(26,5)$. Porównując wartość analizowanego wskaźnika dla województwa małopolskiego oraz warmińsko-mazurskiego, można stwierdzić, że natężenie barier prowadzenia działalności w województwie małopolskim było przeciętnie wyższe o $40 \%$ w porównaniu do województwa warmińsko-mazurskiego.

Tab. 1. Statystyki opisowe dla syntetycznego wskaźnika barier prowadzenia działalności gospodarczej w sekcji H - transport i gospodarka magazynowa od stycznia 2011 roku do października 2016 roku

\begin{tabular}{|l|c|c|c|}
\hline \multicolumn{1}{|c|}{ Województwo } & Średnia & Minimum & Maksimum \\
\hline małopolskie & 37,1 & 30,3 & 41,9 \\
\hline lubuskie & 35,6 & 25,6 & 44,3 \\
\hline łódzkie & 34,8 & 26,9 & 41,7 \\
\hline świętokrzyskie & 33,3 & 23,6 & 45,5 \\
\hline podkarpackie & 32,9 & 25,6 & 36,7 \\
\hline lubelskie & 31,7 & 27,2 & 35,1 \\
\hline opolskie & 30,1 & 23,0 & 35,4 \\
\hline pomorskie & 29,9 & 26,8 & 33,1 \\
\hline śląskie & 29,7 & 26,2 & 32,2 \\
\hline mazowieckie & 29,1 & 25,4 & 37,4 \\
\hline kujawsko-pomorskie & 29,0 & 20,1 & 34,6 \\
\hline zachodniopomorskie & 28,2 & 19,1 & 32,0 \\
\hline wielkopolskie & 27,3 & 22,0 & 36,7 \\
\hline podlaskie & 27,0 & 17,1 & 33,8 \\
\hline dolnośląskie & 26,7 & 20,5 & 42,7 \\
\hline warmińsko-mazurskie & 26,5 & 10,3 & \\
\hline
\end{tabular}

Źródło: obliczenia własne na podstawie danych GUS (2016)

Wśród barier występujących w większości województw największe natężenie w sekcji H w analizowanym okresie miały: niedostateczny popyt, wysokie obciążenia na rzecz budżetu, konkurencja firm krajowych. Z kolei najrzadziej jako bariery dla prowadzenia działalności w większości województw wskazywano niedobór powierzchni usługowej i/lub wyposażenia, koszty zatrudnienia oraz inne bariery. 
Tab. 2. Statystyki opisowe dla syntetycznego wskaźnika barier prowadzenia działalności gospodarczej w sekcji I - zakwaterowanie i usługi gastronomiczne od stycznia 2011 roku do października 2016 roku

\begin{tabular}{|l|c|c|c|}
\hline \multicolumn{1}{|c|}{ Województwo } & Średnia & Minimum & Maksimum \\
\hline podkarpackie & 30,2 & 19,9 & 44,1 \\
\hline wielkopolskie & 29,9 & 18,6 & 36,6 \\
\hline mazowieckie & 29,6 & 25,8 & 35,3 \\
\hline małopolskie & 29,0 & 22,4 & 39,8 \\
\hline podlaskie & 28,6 & 20,7 & 37,3 \\
\hline śląskie & 28,2 & 20,1 & 40,4 \\
\hline zachodniopomorskie & 28,1 & 22,0 & 37,6 \\
\hline łódzkie & 27,6 & 19,0 & 63,6 \\
\hline lubelskie & 27,2 & 9,6 & 41,3 \\
\hline kujawsko-pomorskie & 25,1 & 11,0 & 32,2 \\
\hline pomorskie & 23,7 & 14,9 & 31,1 \\
\hline dolnośląskie & 23,5 & 16,9 & 39,4 \\
\hline świętokrzyskie & 23,4 & 13,2 & 34,7 \\
\hline lubuskie & 22,8 & 13,8 & 35,8 \\
\hline opolskie & 22,4 & 5,8 & 37,4 \\
\hline warmińsko-mazurskie & 18,1 & 6,7 & \\
\hline
\end{tabular}

Źródło: obliczenia własne na podstawie danych GUS (2016)

Nieco inaczej ukształtowała się kolejność województw według wartości syntetycznego wskaźnika barier dla sekcji I - zakwaterowanie i usługi gastronomiczne. Wśród województw o najwyższym średnim poziomie barier prowadzenia działalności w całym analizowanym okresie znalazły się: podkarpackie $(30,2)$, wielkopolskie $(29,9)$ oraz mazowieckie $(29,6)$ (tab. 2). Wśród województw o najniższym natężeniu barier w sekcji I pojawia się tylko jedno województwo, które również znalazło się w tej grupie w przypadku sekcji H: warmińsko-mazurskie $(18,1)$. Składu grupy województw o najkorzystniejszych warunkach prowadzenia działalności w sekcji I i najniższym średnim poziomie barier dla prowadzenia działalności gospodarczej dopełniają województwa: lubuskie $(22,8)$ oraz opolskie $(22,4)$. Pomiędzy województwem o najwyższym poziomie barier dla prowadzenia działalności oraz województwem o najniższym poziomie barier występuje znaczna różnica - syntetyczny wskaźnik barier jest tam wyższy aż o 67\%.

Wśród głównych barier dla prowadzenia działalności w sekcji I - występujących z największym natężeniem w większości województw - pojawia się bariera, która była jedną z najmniej istotnych w sekcji H: koszty zatrudnienia. Zestawu trzech najważniejszych barier dla prowadzenia działalności dopełniają wysokie obciążenia na rzecz budżetu oraz niedostateczny popyt. W grupie trzech najrzadziej występujących barier dla prowadzenia działalności w większości województw znajdują się: niedobór powierzchni usługowej i/lub wyposażenia, trudności z uzyskaniem kredytu oraz inne bariery.

W ostatniej z analizowanych sekcji sektora usług, w sekcji J - informacja i komunikacja, syntetyczny wskaźnik barier przyjmuje najwyższe średnie wartości dla następujących trzech województw: świętokrzyskie $(33,9)$, lubelskie $(31,7)$ oraz lubuskie $(30,1)$ (tab. 3). Powyższy skład województw o najwyższym średnim poziomie barier różni się zatem znacznie od otrzymanego dla sekcji I oraz H. Wśród województw o najniższych wartościach syntetycznego wskaźnika barier w sekcji J znalazły się województwa: opolskie $(24,6)$, łódzkie $(24,4)$ oraz podlaskie $(23,9)$. Wartość średnia syntetycznego 
wskaźnika barier dla województwa świętokrzyskiego (o najwyższym natężeniu barier) jest wyższa o 42\% w porównaniu do województwa podlaskiego (o najniższym natężeniu barier).

Tab. 3. Statystyki opisowe dla syntetycznego wskaźnika barier dla prowadzenia działalności gospodarczej w sekcji J - informacja i komunikacja od stycznia 2011 roku do października 2016 roku

\begin{tabular}{|l|c|c|c|}
\hline \multicolumn{1}{|c|}{ Województwo } & Średnia & Minimum & Maksimum \\
\hline świętokrzyskie & 33,9 & 25,1 & 50,2 \\
\hline lubelskie & 31,7 & 19,6 & 44,6 \\
\hline lubuskie & 30,1 & 16,4 & 35,2 \\
\hline pomorskie & 30,0 & 22,8 & 36,1 \\
\hline zachodniopomorskie & 29,9 & 22,4 & 36,6 \\
\hline wielkopolskie & 29,2 & 20,5 & 36,2 \\
\hline dolnośląskie & 27,6 & 18,8 & 29,2 \\
\hline mazowieckie & 26,6 & 23,2 & 29,3 \\
\hline małopolskie & 25,6 & 20,6 & 31,0 \\
\hline śląskie & 25,6 & 21,0 & 38,9 \\
\hline warmińsko-mazurskie & 25,5 & 15,5 & 33,1 \\
\hline kujawsko-pomorskie & 25,3 & 19,3 & 32,9 \\
\hline podkarpackie & 25,0 & 15,5 & 40,4 \\
\hline opolskie & 24,6 & 16,7 & 31,6 \\
\hline tódzkie & 24,4 & 17,6 & 32,1 \\
\hline podlaskie & 23,9 & 16,7 & \\
\hline
\end{tabular}

Źródło: obliczenia własne na podstawie danych GUS (2016)

Kolejność poszczególnych barier dla prowadzenia działalności w sekcji J różni się nieco w porównaniu do sekcji I oraz H. Głównymi barierami dla prowadzenia działalności w większości województw są: koszty zatrudnienia, wysokie obciążenia na rzecz budżetu oraz niejasne i niespójne przepisy prawne. Z kolei zestaw barier stanowiących najmniejsze utrudnienia przy prowadzeniu działalności gospodarczej w sekcji J jest taki sam, jak w przypadku sekcji I, gdyż obejmuje: niedobór powierzchni usługowej i/lub wyposażenia, trudności z uzyskaniem kredytu oraz inne bariery.

\section{ANALIZA ZALEŻNOŚCI MIĘDZY WSKAŹNIKAMI NATĘŻENIA BARIER DLA PROWADZENIA DZIAŁALNOŚCI ORAZ WSKAŹNIKIEM OGÓLNEGO KLIMATU KONIUNKTURY}

Rozpatrując kształtowanie się barier dla prowadzenia działalności gospodarczej na tle wskaźnika klimatu koniunktury można wskazać, które bariery prowadzenia działalności nasilają się wraz z poprawą koniunktury gospodarczej, a poziom których zmniejsza się. Przeprowadzona analiza korelacji pozwala stwierdzić, że najsilniejsze zależności między koniunkturą gospodarczą oraz kształtowaniem się barier dla prowadzenia działalności występują w przypadku sekcji H oraz J. W obu przypadkach syntetyczny wskaźnik barier wykazuje ujemną znaczącą zależność ze wskaźnikiem klimatu koniunktury (tab. 4). Oznacza to, iż w przypadku tych dwóch sekcji poprawa koniunktury gospodarczej przynosi ogólny spadek natężenia barier dla prowadzenia działalności gospodarczej. 
Tab. 4. Współczynniki korelacji między wskaźnikami barier dla prowadzenia działalności gospodarczej oraz wskaźnikiem ogólnego klimatu koniunktury od stycznia 2011 roku do października 2016 roku w sekcjach H, I oraz J

\begin{tabular}{|l|r|r|c|}
\hline \multicolumn{1}{|c|}{ Bariery dla prowadzenia działalności } & Sekcja H & Sekcja I & Sekcja J \\
\hline Niedostateczny popyt & $-0,846$ & $-0,315$ & $-0,748$ \\
\hline Niedobór wykwalifikowanych pracowników & 0,776 & 0,377 & 0,747 \\
\hline Niedobór powierzchni usługowej i/lub wyposażenia & $-0,222$ & 0,071 & 0,066 \\
\hline Koszty zatrudnienia & $-0,720$ & $-0,071$ & $-0,340$ \\
\hline Trudności z uzyskaniem kredytu & $-0,862$ & $-0,362$ & $-0,501$ \\
\hline Wysokie obciążenia na rzecz budżetu & $-0,685$ & 0,204 & $-0,532$ \\
\hline Konkurencja firm krajowych & $-0,199$ & $-0,213$ & $-0,399$ \\
\hline Konkurencja firm zagranicznych & 0,517 & $-0,281$ & 0,429 \\
\hline Niejasne i niespójne przepisy prawne & $-0,239$ & 0,100 & $-0,582$ \\
\hline Niepewność ogólnej sytuacji gospodarczej & $-0,732$ & $-0,125$ & $-0,830$ \\
\hline Inne & $-0,451$ & 0,110 & $-0,785$ \\
\hline Syntetyczny wskaźnik barier & $-0,828$ & $-0,180$ & $-0,786$ \\
\hline
\end{tabular}

Źródło: obliczenia własne na podstawie danych GUS (2016)

W przypadku sekcji H najsilniejsze ujemne zależności ze wskaźnikiem ogólnego klimatu koniunktury wykazują następujące bariery dla prowadzenia działalności gospodarczej: trudności z uzyskaniem kredytu, niedostateczny popyt, niepewność ogólnej sytuacji gospodarczej oraz koszty zatrudnienia. W sekcji J zestaw barier, w przypadku których stwierdzono najsilniejszy ujemny związek ze wskaźnikiem ogólnego klimatu koniunktury, wykazuje częściowe podobieństwo do zestawu z sekcji H, gdyż obejmuje: niedostateczny popyt, niepewność ogólnej sytuacji gospodarczej oraz inne bariery.

Znacznie słabsze są zależności między ogólnym poziomem koniunktury oraz natężeniem barier dla prowadzenia działalności gospodarczej w sekcji I, gdyż słabe ujemne zależności ze wskaźnikiem ogólnego klimatu koniunktury wykazują tylko cztery bariery: niedostateczny popyt, trudności z uzyskaniem kredytu, konkurencja firm krajowych oraz konkurencja firm zagranicznych.

Analizując wyniki analizy korelacji, warto zwrócić uwagę na dwie bariery, które wykazują w przypadku sekcji $\mathrm{H}$ oraz J umiarkowane lub znaczące dodatnie zależności ze wskaźnikiem ogólnego klimatu koniunktury. Zestaw ten tworzą: niedobór wykwalifikowanych pracowników oraz konkurencja firm zagranicznych. Oznacza to, że lepsza koniunktura gospodarcza przynosi częstsze występowanie powyższych barier jako czynników ograniczających prowadzenie działalności gospodarczej w sekcji H oraz J.

Analiza korelacji między średnim wskaźnikiem ogólnego klimatu koniunktury dla sekcji H, I i J oraz średnim syntetycznym wskaźnikiem barier dla prowadzenia działalności gospodarczej w tych sekcjach, przeprowadzona dla każdego z województw, pozwala stwierdzić, iż siła zależności pomiędzy tymi dwiema zmiennymi w poszczególnych województwa wykazuje zróżnicowanie, przy czym w większości przypadków występują zależności ujemne (ryc. 1). Najsilniejsze ujemne zależności występują w województwach: śląskim, zachodniopomorskim oraz opolskim. Oznacza to, że w tych województwach wraz z poprawą koniunktury gospodarczej w kolejnym miesiącach można spodziewać się spadku barier dla prowadzenia działalności gospodarczej w sekcjach $\mathrm{H}$, I oraz J. 
Ryc. 1. Ranking województw według wartości współczynnika korelacji między syntetycznym wskaźnikiem barier dla prowadzenia działalności gospodarczej oraz wskaźnikiem ogólnego klimatu koniunktury w sekcjach H, I oraz J od stycznia 2011 roku do października 2016 roku

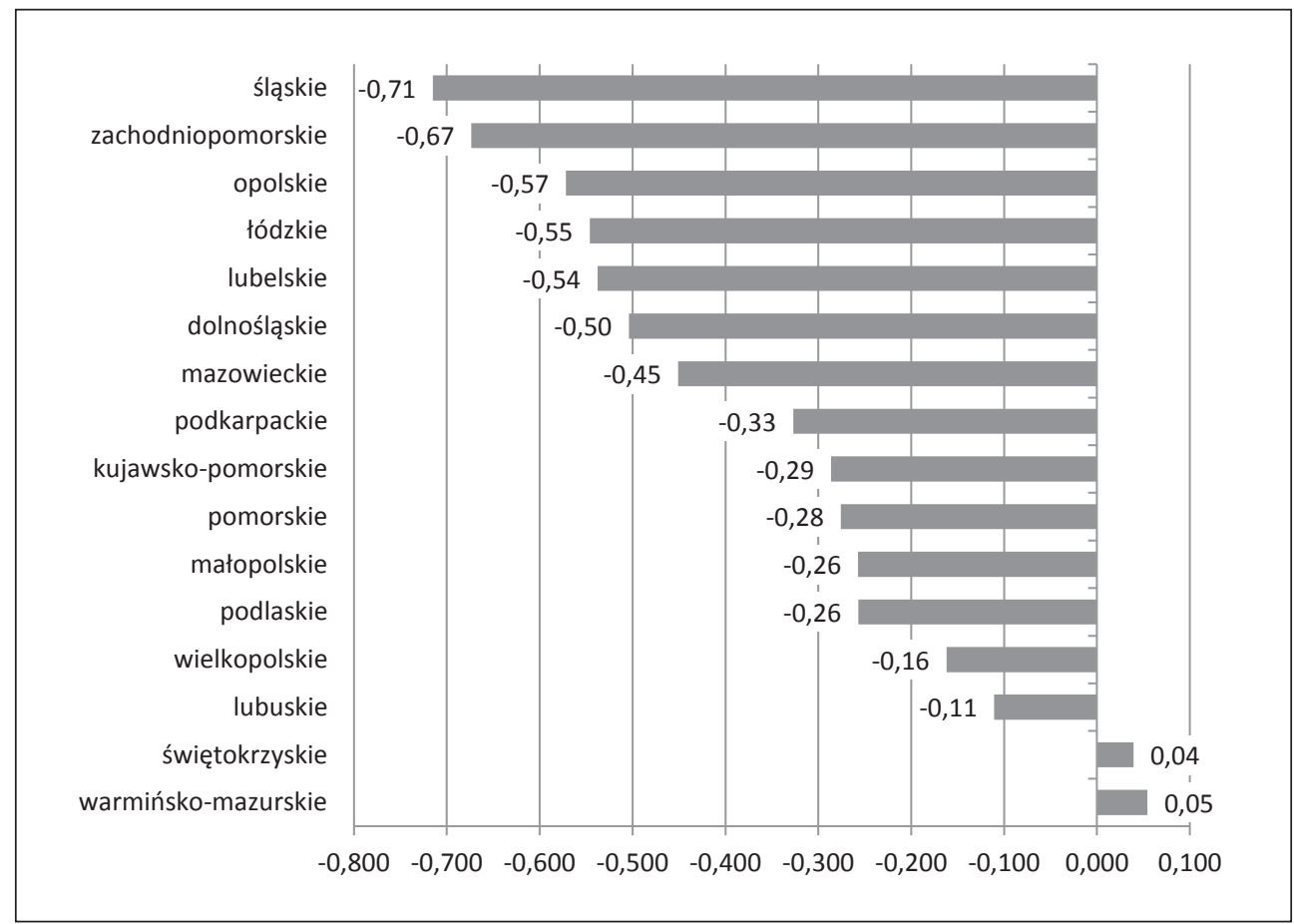

Źródło: obliczenia własne na podstawie danych GUS (2016)

Natomiast w przypadku czterech województw uzyskane wartości współczynników korelacji wskazują na brak zależności między koniunkturą gospodarczą oraz poziomem barier dla prowadzenia działalności w trzech analizowanych sekcjach sektora usług. Sytuacja taka występuje w województwach: warmińsko-mazurskim, świętokrzyskim, lubuskim oraz wielkopolskim.

\section{SEGMENTACJA WOJEWÓDZTW NA PODSTAWIE WSKAŹNIKÓW KONIUNKTURY W 2011 I 2016 ROKU}

Występujące różnice między województwami w zakresie natężenia barier dla prowadzenia działalności, jak również obserwowane od stycznia 2011 roku do października 2016 roku korelacje między poziomem koniunktury gospodarczej oraz poziomem barier dla działalności skłaniają do przeprowadzenia analizy porównawczej w tym zakresie między grupami województw o podobnym poziomie koniunktury gospodarczej. W tym celu zostaną wyodrębnione grupy województw o podobnym poziomie koniunktury gospodarczej na podstawie średnich wartości zmiennych dla 2011 roku oraz 2016 roku. Podstawą segmentacji jest zestaw trzech zmiennych, obejmujących wskaźniki ogólnego klimatu koniunktury dla sekcji H, I oraz J. Segmentacja została przeprowadzona z zastosowaniem metody Warda. Jako zmienne profilujące segmenty zostały przyjęte syntetyczne wskaźniki barier. Pozwala to na porównanie kształtowania się barier 
dla prowadzenia działalności między grupami województw o zbliżonym poziomie koniunktury gospodarczej.

Na podstawie dendrogramu uzyskanego metodą Warda dla 2011 roku można wyodrębnić cztery segmenty województw (ryc. 2). Poszczególne segmenty obejmują od dwóch do sześciu województw.

Ryc. 2. Diagram drzewa uzyskany metodą Warda dla 2011 roku

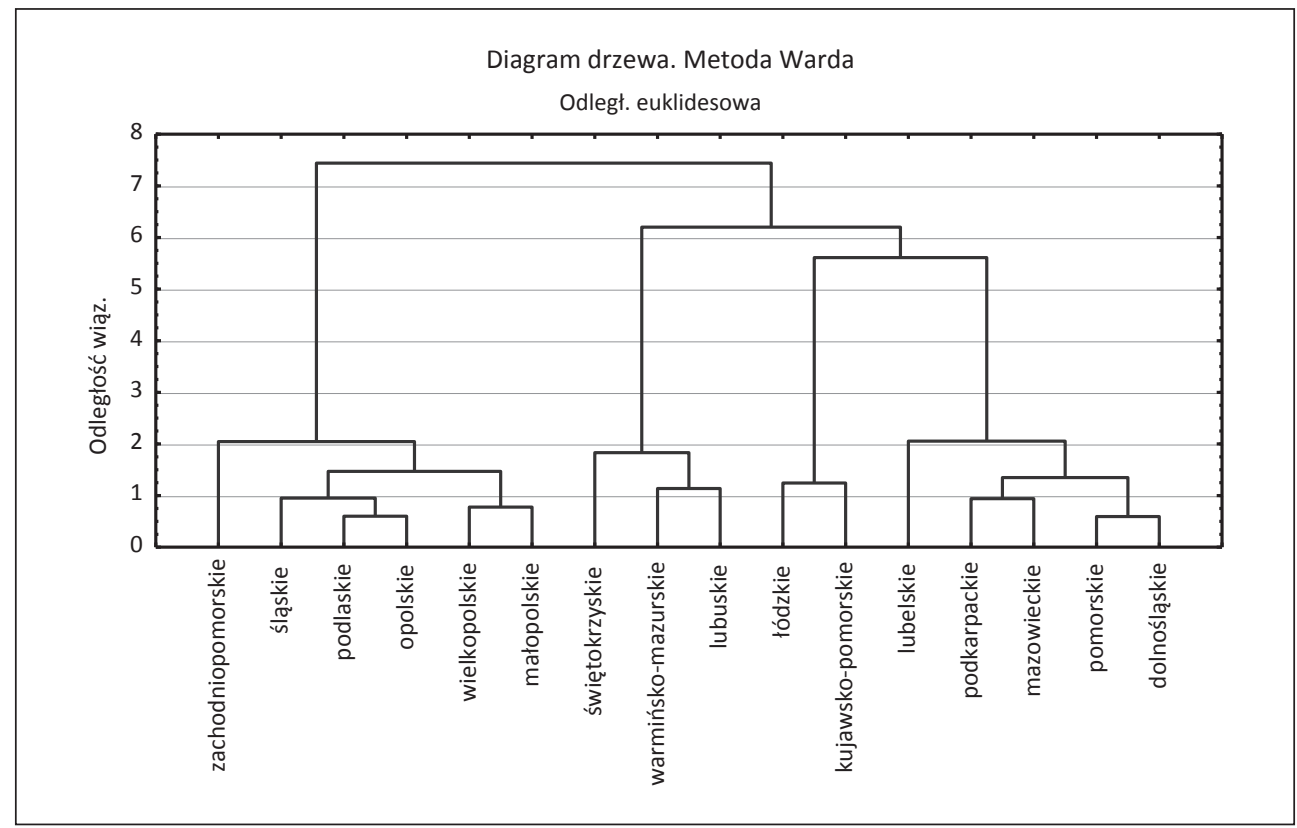

Źródło: obliczenia własne na podstawie danych GUS (2016)

Tab. 5. Charakterystyka segmentów otrzymanych w 2011 roku

\begin{tabular}{|l|r|r|r|r|}
\hline \multicolumn{6}{|c|}{ Wyszczególnienie } & Segment A & Segment B & Segment C & Segment D \\
\hline \multicolumn{7}{|c|}{ zmienne segmentacyjne } \\
\hline Wskaźnik ogólnego klimatu koniunktury - sekcja H & $-6,4$ & $-0,7$ & $-9,9$ & $-32,9$ \\
\hline Wskaźnik ogólnego klimatu koniunktury - sekcja I & 4,9 & 5,1 & $-14,7$ & 6,0 \\
\hline Wskaźnik ogólnego klimatu koniunktury - sekcja J & 16,8 & $-15,6$ & 7,6 & 2,7 \\
\hline \multicolumn{7}{|c|}{ zmienne profilujące } & 31,1 & 26,5 & 30,7 & 40,2 \\
\hline Syntetyczny wskaźnik barier - sekcja H & 27,7 & 21,3 & 30,8 & 29,0 \\
\hline Syntetyczny wskaźnik barier - sekcja I & 25,8 & 30,9 & 25,2 & 24,2 \\
\hline
\end{tabular}

Źródło: obliczenia własne na podstawie danych GUS (2016)

Segment A obejmuje województwa: dolnośląskie, lubelskie, podkarpackie, mazowieckie oraz pomorskie. Wyróżnia się najkorzystniejszą koniunkturą w sekcji J oraz nieco korzystniejszą niż w całym kraju koniunkturą w sekcjach H oraz I. Pod względem natężenia barier dla prowadzenia działalności prezentuje się natomiast nieco korzystniej od przeciętnego ich natężenia w całym kraju, jednakże na tle pozostałych segmentów klasyfikuje się na drugim lub trzecim miejscu w zależności od sekcji. 
Segment B skupia trzy województwa: lubuskie, świętokrzyskie oraz warmińsko-mazurskie. Wyróżnia się najkorzystniejszą koniunkturą w sekcji H oraz najsłabszą w sekcji J. Warto podkreślić, iż konsekwencją tego jest występowanie również najkorzystniejszej (najniższej) wartości syntetycznego wskaźnika barier w sekcji H oraz najmniej korzystnej (najwyższej) wartości tego wskaźnika w sekcji J.

Segment C obejmuje sześć województw: małopolskie, opolskie, podlaskie, śląskie, wielkopolskie oraz zachodniopomorskie. Wyróżnia się najsłabszą koniunkturą w sekcji I oraz zbliżoną do panującej w całym kraju w pozostałych sekcjach. Efektem tej sytuacji jest najmniej korzystne kształtowanie się syntetycznego wskaźnika barier w sekcji I oraz poziom zbliżony do ogólnokrajowego w przypadku pozostałych sekcji.

Segment D tworzony jest przez dwa województwa: kujawsko-pomorskie oraz łódzkie. Charakteryzuje się najsłabszą koniunkturą w sekcji H oraz najlepszą w sekcji I. Prowadzi to do występowania najwyższego natężenia barier dla prowadzenia działalności w sekcji H. Warto zauważyć jednak, że segment ten wyróżnia się również najniższym poziomem barier dla prowadzenia działalności w sekcji J, pomimo ogólnego klimatu koniunktury nieco słabszego niż w całym kraju.

Na podstawie dendrogramu uzyskanego metodą Warda dla 2016 roku można wyodrębnić tylko dwa segmenty województw. Segment A obejmuje dziewięć województw: lubuskie, świętokrzyskie, warmińsko-mazurskie, opolskie, wielkopolskie, kujawsko-pomorskie, dolnośląskie, lubelskie, mazowieckie. Wyróżnia się znacznie korzystniejszą niż w segmencie B koniunkturą w sekcji I oraz J. Konsekwencją jest niższy poziom barier dla prowadzenia działalności w tych sekcjach w porównaniu do segmentu B, przy czym warto zaznaczyć, iż największe różnice w zakresie natężenia barier dla prowadzenia działalności występują w przypadku sekcji J (tab. 6).

Ryc. 3. Diagram drzewa uzyskany metodą Warda dla 2016 roku

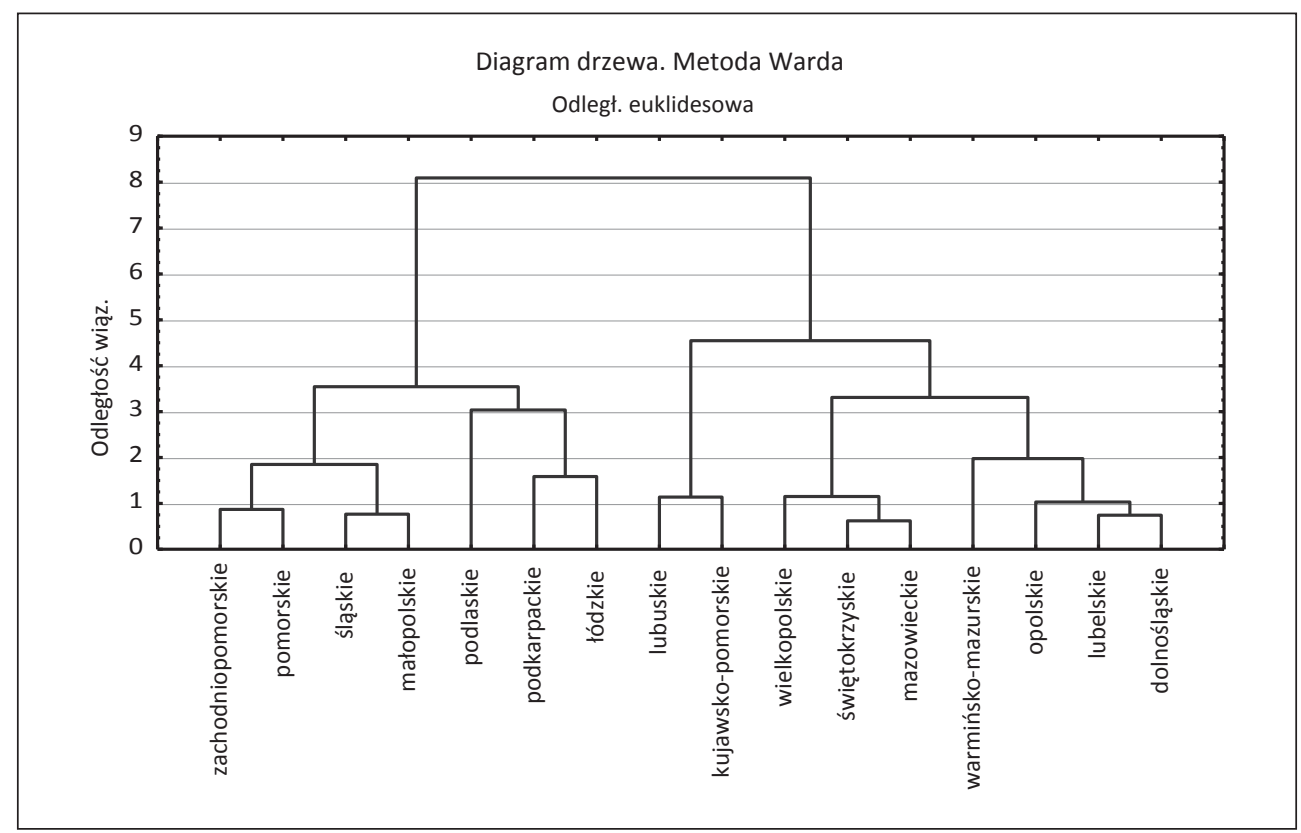

Źródło: obliczenia własne na podstawie danych GUS (2016) 
Tab. 6. Charakterystyka segmentów otrzymanych w 2016 roku

\begin{tabular}{|c|c|c|}
\hline Wyszczególnienie & Segment A & Segment B \\
\hline \multicolumn{3}{|c|}{ zmienne segmentacyjne } \\
\hline Wskaźnik ogólnego klimatu koniunktury - sekcja H & $-1,4$ & 5,8 \\
\hline Wskaźnik ogólnego klimatu koniunktury - sekcja I & 9,9 & $-3,7$ \\
\hline Wskaźnik ogólnego klimatu koniunktury - sekcja J & 18,5 & 5,8 \\
\hline \multicolumn{3}{|c|}{ zmienne profilujące } \\
\hline Syntetyczny wskaźnik barier - sekcja H & 29,1 & 29,8 \\
\hline Syntetyczny wskaźnik barier - sekcja I & 26,2 & 26,3 \\
\hline Syntetyczny wskaźnik barier - sekcja J & 25,5 & 28,7 \\
\hline
\end{tabular}

Źródło: obliczenia własne na podstawie danych GUS (2016)

Tab. 7. Skład segmentów otrzymanych w 2011 i 2016 roku

\begin{tabular}{|c|c|c|c|}
\hline \multicolumn{4}{|c|}{2011} \\
\hline Segment A & Segment B & Segment C & Segment D \\
\hline $\begin{array}{l}\text { dolnośląskie } \\
\text { lubelskie } \\
\text { podkarpackie } \\
\text { mazowieckie } \\
\text { pomorskie }\end{array}$ & $\begin{array}{l}\text { lubuskie } \\
\text { świętokrzyskie } \\
\text { warmińsko-mazurskie }\end{array}$ & $\begin{array}{l}\text { małopolskie } \\
\text { opolskie } \\
\text { podlaskie } \\
\text { śląskie } \\
\text { wielkopolskie } \\
\text { zachodniopomorskie }\end{array}$ & $\begin{array}{l}\text { kujawsko-pomorskie } \\
\text { łódzkie }\end{array}$ \\
\hline \multicolumn{4}{|c|}{2016} \\
\hline \multicolumn{2}{|c|}{ Segment A } & \multicolumn{2}{|c|}{ Segment B } \\
\hline \multicolumn{2}{|c|}{$\begin{array}{l}\text { zachodniopomorskie } \\
\text { pomorskie } \\
\text { śląskie } \\
\text { małopolskie } \\
\text { podlaskie } \\
\text { podkarpackie } \\
\text { łódzkie }\end{array}$} & \multicolumn{2}{|l|}{$\begin{array}{l}\text { lubuskie } \\
\text { świętokrzyskie } \\
\text { warmińsko-mazurskie } \\
\text { opolskie } \\
\text { wielkopolskie } \\
\text { kujawsko-pomorskie } \\
\text { dolnośląskie } \\
\text { lubelskie } \\
\text { mazowieckie }\end{array}$} \\
\hline
\end{tabular}

Źródło: obliczenia własne na podstawie danych GUS (2016)

Segment A otrzymany dla 2016 roku tworzony jest przez aż cztery województwa z segmentu C z 2011 roku, dwa województwa z segmentu A oraz jedno województwo z segmentu D. Z kolei segment B w 2016 roku tworzą wszystkie województwa z segmentu B z 2011 roku oraz pozostałe województwa z segmentów A, C i D. Powyższe wyniki wskazują, że dobra koniunktura gospodarcza danego województwa w 2011 roku na tle pozostałych nie oznacza dobrej koniunktury również w 2016 roku. W konsekwencji można zaobserwować przesunięcia województw z segmentów o lepszej koniunkturze w 2011 roku do segmentu o gorszej koniunkturze w 2016 roku.

\section{ZAKOŃCZENIE}

Przeprowadzone analizy pozwalają na sformułowanie pewnych wniosków dotyczących kształtowania się barier dla prowadzenia działalności na tle koniunktury gospodarczej w wybranych sekcjach sektora usług. 
Kolejność województw w rankingu według średniego poziomu barier w poszczególnych sekcjach sektora usług (H, I oraz J) dość znacznie się różni. Niewiele jest województw o wysokim poziomie barier równocześnie we wszystkich trzech sekcjach.

Na tle ogółu województw najniższym poziomem barier w analizowanych sekcjach sektora usług i najkorzystniejszymi warunkami prowadzenia działalności wyróżniają się województwa: dolnośląskie, podlaskie, opolskie, warmińsko-mazurskie oraz kujawsko-pomorskie. Województwa te zajmowały korzystne pozycje pod względem wysokości syntetycznego wskaźnika barier przynajmniej w dwóch spośród trzech analizowanych sekcji sektora usług. Najtrudniejsze warunki prowadzenia działalności - na co wskazuje relatywnie wysoki poziom barier przynajmniej w dwóch spośród trzech analizowanych sekcji sektora usług - występowały w województwach: małopolskim, lubelskim, świętokrzyskim, lubuskim oraz podkarpackim.

Wśród determinant prowadzenia działalności gospodarczej w analizowanych trzech sekcjach sektora usług można wskazać kilka barier, które wykazują silne ujemne zależności od wskaźnika ogólnego klimatu koniunktury - niedostateczny popyt, niepewność ogólnej sytuacji gospodarczej. W przypadku jednej z barier (niedobór wykwalifikowanych pracowników) dla dwóch spośród trzech analizowanych sekcji stwierdzone zostały silne dodatnie zależności.

Zależności między natężeniem barier prowadzenia działalności oraz ogólnym klimatem koniunktury na poziomie województw są słabsze niż na poziomie całego kraju, przy czym w znacznej większości przypadków pozostają ujemne.

Pozycja danego województwa na tle pozostałych województw pod względem poziomu koniunktury ulega zmianie w czasie. Prowadzi to do zmiany składu segmentów województw o podobnym poziomie koniunktury w sektorze usług wyodrębnionych w 2011 oraz 2016 roku. Spośród województw, które znalazły się w 2011 roku w segmentach A oraz B, charakteryzujących się najkorzystniejszym poziomem koniunktury w analizowanych sekcjach sektora usług, w 2016 roku jedynie dwa województwa zostały sklasyfikowane w segmencie A, cechującym się korzystniejszym poziomem koniunktury (podkarpackie i pomorskie).

Wraz z poprawą koniunktury gospodarczej w wyodrębnionych segmentach województw zasadniczo zmniejsza się natężenie barier dla prowadzenia działalności gospodarczej.

\section{Literatura \\ References}

Badanie koniunktury gospodarczej (2016, 17 grudnia). Główny Urząd Statystyczny. Pozyskano z http://stat.gov.pl/download/gfx/portalinformacyjny/pl/defaultaktualnosci/5516/5/7/1/ badanie_koniunktury_gospodarczej_2016_05_25.pdf

Doing Business w Polsce 2015 (2016, 17 grudnia). Pozyskano z http://polish.doingbusiness.org Ferreira, L., Hitchcock, D.B. (2009). A Comparison of Hierarchical Methods for Clustering Functional Data. Communications in Statistics: Simulation and Computation, 9, 235-243.

GUS (2016, 21 października). Pozyskano z http://stat.gov.pl/

Hands, S., Everitt, B. (1987). A Monte Carlo study of the recovery of cluster structure in binary data by hierarchical clustering techniques. Multivariate Behavioral Research, 2, 1925-1949.

Leoński, W. (2014). Bariery funkcjonowania małych i średnich przedsiębiorstw w Polsce. Zeszyty Naukowe Wydziału Nauk Ekonomicznych Politechniki Koszalińskiej, 18, 95-108.

Mikołajczak, P., Skikiewicz, R. (2014). Bariery prowadzenia działalności jako determinanty sytuacji finansowej przedsiębiorstw sektora budowlanego. Studia Ekonomiczne, 82(3), 361-380. 
Pierścionek, Z. (2003). Strategie konkurencji i rozwoju przedsiębiorstwa. Warszawa: Wydawnictwo Naukowe PWN.

Przedsiębiorczość w Polsce (2014) (2016, 17 grudnia). Ministerstwo Gospodarki. Pozyskano z https://www.mr.gov.pl/media/15513/Raport_o_przedsiebiorczosci_2014.pdf

Skikiewicz, R. (2014). Bariery w działalności instytucji finansowych na tle zmian sytuacji gospodarczej Polski. Prace Naukowe Uniwersytetu Ekonomicznego we Wrocławiu, 330, 352-60.

Skikiewicz, R. (2016). Barriers to business and economic situation in the services sector in the EU countries. Copenhagen: Paper presented at 33rd CIRET Conference.

Warunki prowadzenia firm w Polsce (2016, 17 grudnia). Pozyskano z http://zpp.net.pl/files/ manager/file-89fbe33aaeeee96c88c42a1d5ef1a6e6.pdf

Zdrajkowska, H., Zakrzewska-Bielawska, A. (2006). Bariery rozwoju małych i średnich przedsiębiorstw w Polsce i Wielkiej Brytanii. W: I.K. Hejduk, J. Korczak (red.). Gospodarka oparta na wiedzy. Koszalin: Wydawnictwo Politechniki Koszalińskiej, 723-733.

Jan Fazlagić, dr hab., profesor nadzwyczajny Uniwersytetu Ekonomicznego w Poznaniu. Tematyka badawcza dotyczy: zarządzania szkołą, edukacji, innowacyjności w oświacie, zarządzania kapitałem intelektualnym, marketingu i projektowania usług. Współautor wielu ekspertyz dla firm i instytucji sektora publicznego. Stypendysta Fulbright Senior Scholarship (2006-2007) oraz Marie Curie Research Fellowship (2002-2003). Autor dziesięciu książek i ponad 250 artykułów naukowych i popularnonaukowych.

Jan Fazlagić, Ph.D., is a professor in management at the Poznan University of Economics and Business in Poznań. His research interests include knowledge management, intellectual capital, service design, education and innovation management. He was a Senior Fulbright Scholar at Sam Houston University, TX, USA and Marie Curie Research Fellow at the Centre for Social Innovation (zsi.at) in Vienna, Austria. He is the author of the first Polish Intellectual Capital Report in a Higher Education Institution (2004). He is an author of 10 books and over 250 research papers. Prof. Fazlagić has participated in numerous research projects including Innovation Report on the Polish Pharma Sector (2012), Service Design (2013) and the national survey on the trust in Polish business sector (2015). He is active as a business consultant and trainer. He also supports the development of European head teachers by organising seminars and conferences aimed at improving leadership skills and marketing competences in schools.

\title{
Adres/address:
}
Uniwersytet Ekonomiczny w Poznaniu
Katedra Badań Rynku i Usług
al. Niepodległości 10, 61-875 Poznań, Polska
e-mail: jan.fazlagic@ue.poznan.pl

Robert Skikiewicz, dr nauk ekonomicznych Uniwersytetu Ekonomicznego w Poznaniu. Podejmowana problematyka badawcza obejmuje głównie zagadnienia z zakresu analizy koniunktury gospodarczej oraz na rynku bankowym. Ponadto zainteresowania naukowe autora obejmują analizę zachowań gospodarstw domowych na rynku usług finansowych.

Robert Skikiewicz, Ph.D. Poznań University of Economics and Business. Undertaken research topics include issues concerning the analysis of business cycle in the whole economy, as well as in the banking market. In addition, the author's research interests include analysis of the behaviour of households in the financial services market.

\section{Adres/address:}

\author{
Uniwersytet Ekonomiczny w Poznaniu \\ Katedra Badań Rynku i Usług \\ al. Niepodległości 10, 61-875 Poznań, Polska \\ e-mail: robert.skikiewicz@ue.poznan.pl
}

